\title{
IMPACT OF FEDERAL GOVERNMENT EXPENDITURE IN EDUCATION ON NIGERIA ECONOMIC GROWTH (1980 - 2018)
}

\author{
O.S. BEWAJI ${ }^{*}$, S.A. AGBONJINMI ${ }^{2}$ AND S.T. OMOJUYIGBE ${ }^{3}$ \\ ${ }^{1 *}$ Department of Economics, University of Abuja, Abuja, Nigeria. \\ ${ }^{2}$ Department of Economics, University of Abuja, Abuja, Nigeria. \\ ${ }^{3}$ Department of Economics, Veritas University, Abuja, Nigeria.
}

Correspondence Email: samuelbewaji@gmail.com; 09057517411.

\begin{abstract}
This research work analyzed the impacts of Federal government expenditure in education on Nigeria economic growth. The study used secondary data from 1980 to 2018 and the information gathered was presented and analyzed through E-view. The study makes use of analytical statistics for the analysis of the data collected. The Ordinary Least Square (OLS), and ADF Test were employed in order for certainty, reliability of the results and to guard against obtaining spurious results. Adaptive model was employed in order to capture the short and long run effect of Federal Government expenditure in education (GEDU) on economic growth and the hypothesis say that, there is no long run impact of Federal government expenditure in education on Nigeria economic growth. However, the findings show that there is positive impact between RGDP and GEDU, and Comparing GEDU of the short run and the long run, it could be seen that the impact of Federal government expenditure in education is greater in the long run with $7.5 \%$ than in the short run. However, the challenges observed are instability, and inadequate government expenditure in education. Therefore the study recommends that quality education make labour more productive and the multiplier effect will cause an increase in aggregate output of the economy.
\end{abstract}

Keywords: Education, economic growth and econometric adaptive analysis. 


\section{INTRODUCTION}

Nigeria has the largest economy in West Africa and is the most populous country in Africa, with an estimated population of 200 million people. There are 36 states and the Federal Capital Territory (FCT) comprising 774 local government areas. The economy depends so much on the exploration and exportation of oil and gas. However, Human capital development has one of the important determinant factors for economic growth can never be over emphasized, taken evidence from the times of prominent classical and neoclassical economist such as Adam Smith, Romer, Lucas and Solow.

Education as an investment secures returns in the form of skilled manpower that geared to the needs of development, both for accelerating economic development and for improving the quality of the society [1]. However, the significance of education in developing a country's economy cannot be overstated, because it has a lot of economic impact across. In explaining some significant roles of education in economic development, i.e when people that formal education, there output per labour will be increase which will directly or indirectly increase the aggregate output of the country. Apart from the role of education in every sectors of the economy, formal education also play a significant role in agricultural sector, because when farmers are educated, their rightful application of knowledge will boot their output. According to her, education also attracts direct financial returns in form of earnings differential among graduates and relatively minimal in comparison to others with lesser educational qualifications. This is mostly found in the organized private and public institutions [2].

Education also contributes immensely to technological development both in terms of acquisition, adaptation, and capital widening and deepening. An educated man is more efficient with a high degree of efficiency in terms of practical and applications, capacity and least waste. Educations' significance can also be perceived in the socio-political stability of a nation which can be measure in qualitative and quantitative policies in government.

However, it is so unfortunate to see that, despite the enormous impact of education to all the sectors in the country, education sector is poorly funded in Nigeria. This poor funding is not limited to inadequate infrastructure alone but also on the incentive structure of staff in the school system, lack of resource for research and development in schools towards inventions and innovations in the country of which all these inefficiency affect the economic growth of this country negatively.

This paper attempts an empirical analysis of Federal government expenditure in education on Nigeria economic growth between the periods 1980 to 2018. In section II we discussed the related work of different scholars that are in line with the study. Section III contains the methodology adapted in this study. Section IV we present our results and discussed the findings. Section V we made some concluding remarks based on our findings.

\section{RELATED WORK}

A lot of definitions of the concept 'education' abound in literature. According to Adeyemo, it is the acquisition of not only knowledge but societal rules and regulations [3]. Omonkalo views it as a major tool for national socio - economic development and for individual's socio-economic empowerment and poverty reduction. Education is also a key development index and plays complementary role for overall individual, social and national development [4]. From whichever way it is viewed, it is a fact that education gives room for an economic 
investment that raises the quality of life, improves health, productivity in market and nonmarket world, increase individual's access to paid employment as well as facilitates social and political participation of an individual in the development of the Nation.

Several empirical studies that have been undertaken to identify the possible nexus between economic growth and educational capital results vary depending on the model specifications and the data set in use. Regardless of the precise model that is adopted, there seems to be strong evidence that higher educational inputs increase productivities and economic growth.

A study carried out by Abiodun and Iyiola, examined the contribution of education to Nigeria economy. They noted that human capital formation is important in achieving a sustainable economic growth and to achieve this contribution, there is need for quality and quantity investment in education. Employing time series data which spanned between 1980 to 2008 and analyzed with ordinary least square discovered that education investment has direct and significant influence on economic growth. They recommended that government at all levels should increase funding on various segments of education in the country [5].

Oluwatobi and Olurani empirically examined the nexus between human capital development of the government and economic growth in Nigeria. The basic objective of the study was to examine the impact of government recurrent and capital expenditure on education and health in Nigeria and their effect on economic growth. The study used augmented solo growth model. Employing econometric technique, the result reveals that there is a positive relationship between government recurrent expenditure on human capital development (education and health) and economic growth. The policy implication is that funding of capital expenditure on education and health is required in the Nigerian economy [6].

\section{Model Specification}

\section{METHODOLOGY}

A model is adapted from Greg and Agboro [7], however, the model was modified by forming adaptation round the model in order to capture the short and long run impact of Federal Government expenditure in education (GEDE) on economic growth. The main model is given bellow.

$\mathrm{GDP}_{\mathrm{t}}=\mathrm{F}\left(\mathrm{GEDE}_{\mathrm{t}}{ }^{*}\right)$

$\mathrm{GDP}_{\mathrm{t}}=\beta 0+\beta 1 \mathrm{GEDE}_{\mathrm{t}}^{*}+\mu_{\mathrm{t}}$

\section{Adaptive Expectation Model}

$\mathrm{GEDE}_{\mathrm{t}}{ }^{*}-\mathrm{GEDE}_{\mathrm{t}-1}{ }^{*}=\lambda\left(\mathrm{GEDE}_{\mathrm{t}}-\mathrm{GEDE}_{\mathrm{t}-1}{ }^{*}\right)$

Where GEDE $_{t}{ }^{*}$ is actual level

$\mathrm{GEDE}_{\mathrm{t}-1} *$ is desired level

$\lambda$ is the coefficient of expectation.

$$
\begin{aligned}
& \operatorname{GEDE}_{\mathrm{t}}{ }^{*}=\lambda \mathrm{GEDE}_{\mathrm{t}}+\mathrm{GEDE}_{\mathrm{t}-1}{ }^{*}-\lambda \mathrm{GEDE}_{\mathrm{t}-1}{ }^{*} . \\
& \mathrm{GEDE}_{\mathrm{t}}{ }^{*}=\lambda \mathrm{GEDE}_{\mathrm{t}}+(1-\lambda) \mathrm{GEDE}_{\mathrm{t}-1}{ }^{*} \ldots \ldots \ldots
\end{aligned}
$$




\section{Substitute equation 5 into equation 2}

$\mathrm{GDP}_{\mathrm{t}}=\beta_{0}+\beta_{1} \lambda \mathrm{GEDE}_{\mathrm{t}}+(1-\lambda) \mathrm{GEDE}_{\mathrm{t}-1}{ }^{*}+\mu_{\mathrm{t}}$.
$\mathrm{GDP}_{\mathrm{t}}=\beta_{0}+\lambda \beta_{1} \mathrm{GEDE}_{\mathrm{t}}+(1-\lambda) \mathrm{GEDE}_{\mathrm{t}-1}{ }^{*}+\mu_{\mathrm{t}}$

\section{Lag equation 2 by 1 period}

$\mathrm{GDP}_{\mathrm{t}-1}=\beta_{0}+\beta_{1} \mathrm{GEDE}_{\mathrm{t}-1}{ }^{*}+\mu_{\mathrm{t}-1}$

Multiply equation 8 by $(1-\lambda)$

$(1-\lambda)$ is the rate of adjustment and it will help us to capture the long run impact.

$(1-\lambda) \operatorname{GDP}_{\mathrm{t}-1}=(1-\lambda) \beta_{0}+(1-\lambda) \beta_{1} \operatorname{GEDE}_{\mathrm{t}-1}{ }^{*}+(1-\lambda) \mu_{\mathrm{t}-1}$

$(1-\lambda) \mathrm{GDP}_{\mathrm{t}-1}=\beta_{0^{-}} \lambda \beta_{0}+(1-\lambda) \beta_{1} \mathrm{GEDE}_{\mathrm{t}-1}{ }^{*}+(1-\lambda) \mu_{\mathrm{t}-1}$

Subtract equation (10) from equation (7)

$\operatorname{GDP}_{\mathrm{t}}-(1-\lambda) \mathrm{GDP}_{\mathrm{t}-1}=\beta_{0^{-}}\left(\beta_{0^{-}} \lambda \beta_{0}\right)+\lambda \beta_{1} \mathrm{GEDE}_{\mathrm{t}}-(1-\lambda) \beta_{1} \mathrm{GEDE}_{\mathrm{t}-1}{ }^{*}+(1-\lambda) \mathrm{GEDE}_{\mathrm{t}-1}{ }^{*}-(1-$ 入) $\mu_{\mathrm{t}-1}+\mu_{\mathrm{t}}$

$\mathrm{GDP}_{\mathrm{t}}-(1-\lambda) \mathrm{GDP}_{\mathrm{t}-1}=\lambda \beta_{0}+\lambda \beta_{1} \mathrm{GEDE}_{\mathrm{t}}+\mu_{\mathrm{t}^{-}}(1-\lambda) \mu_{\mathrm{t}-1}$

$\mathrm{GDPt}=\lambda \beta_{0}+\lambda \beta_{1} \mathrm{GEDE}_{\mathrm{t}}+(1-\lambda) \mathrm{GDP}_{\mathrm{t}-1}+\mu_{\mathrm{t}}-(1-\lambda) \mu_{\mathrm{t}-1}$

$\mathrm{GDP}_{\mathrm{t}}=\lambda \beta 0+\lambda \beta_{1} \mathrm{GEDE}_{\mathrm{t}}+(1-\lambda) \mathrm{GDP}_{\mathrm{t}-1}+\mathrm{V}_{\mathrm{t}}$

Where: $\mathrm{Vt}=\mathrm{ut}-(1-\lambda) \mathrm{u}_{\mathrm{t}-1}$

Hence, equation 13 is the moving model to test the hypotheses outline above.

\section{RESULTS AND DISCUSSION}

\section{General Regression Result}

Dependent Variable: RGDP

\begin{tabular}{|l|r|r|r|r|}
\hline $\begin{array}{l}\text { Independent } \\
\text { Variables }\end{array}$ & Coefficient & Standard Error & \multicolumn{1}{|c|}{$\begin{array}{c}\text { t- } \\
\text { Statistic }\end{array}$} & \multicolumn{2}{l|}{ Prob } \\
\hline $\begin{array}{l}\text { Constant } \\
\text { Intercept }\end{array}$ & 52187.54 & 27231.34 & 2.916451 & 0.0216 \\
\hline GEDU & 0.414320 & 0.117322 & 3.531479 & 0.0333 \\
\hline RGDP(-1) & 0.925321 & 0.025231 & 36.67358 & 0.0000 \\
\hline $\mathbf{R}^{2}=0.884413$ & & $\begin{array}{l}\text { F- } \\
\text { Statistic=929.1597 }\end{array}$ & & \\
\hline $\begin{array}{l}\text { Adjusted } \\
\mathbf{R}^{2}=0.834101\end{array}$ & & $\begin{array}{l}\text { D-W } \\
\text { Statistic=1.582312 }\end{array}$ & & \\
\hline
\end{tabular}

Source: Author's calculation, 2020. 
From the estimated regression result, the coefficients of the independent variables are positively related to RGDP i.e. GEDU, and RGDP(-1) are positively related to RGDP. All the explanatory variables are jointly significant to RGDP i.e predicator variables jointly explained $88 \%$ of GDP while the remaining $12 \%$ could be due to the effect of extraneous variables which are not captured in the model.

$\mathrm{RGDP}_{\mathrm{t}}=\lambda \beta 0+\lambda \beta 1 \mathrm{GEDU}_{\mathrm{t}}+(1-\lambda) \mathrm{RGDP}_{\mathrm{t}-1}+\mathrm{Vt}$

The equation 1 is the moving model to test the hypotheses outlined in chapter one. In adaptive model, after ADF test has being carried out, for OLS to be applicable, adaptation needs to be formed round the explanatory variable $\left(\mathrm{GEDU}_{\mathrm{t}}{ }^{*}\right)$ and at equation 1 , OLS is applicable.

$\mathrm{RGDP}=52187.54+0.414320 \mathrm{GEDU}+0.925321 \mathrm{RGDP}(-1)$

The equation 2 shows that a unit increase in GEDU on the average will lead to 0.414320 unit increase in RGDP holding other variables constant which shows the short run impact of GEDU on RGDP. However, for long run impact to be estimated there is need for coefficient of adjustment $(\lambda)$.

\section{For the coefficient of adjustment}

The result from statistical package (E-view 8) shows that federal government expenditure in education (GEDU) and $\operatorname{RGDP}(-1)$ have positive impact on the Nigeria economy development.

$\lambda=(1-0.925321)=0.074679$, it implies that only $7.5 \%$ of the discrepancy between the desired and actual economic growth are eliminated and hence, is a moderate adjustment. However, the long run equation is given below by dividing the short run equation by the value of $\lambda$.

\section{THE LONG RUN EQUATION}

$\mathrm{RGDP}=698824.8+5.5480 \mathrm{GEDU}$

Comparing GEDU of the short run and the long run, it could be seen that the impact of government expenditure in education is greater in the long run than in the short run. This result shows that a unit increase in GEDU on the average will lead to 0.414320 increase in RGDP holding other variables constant which shows the short run impact of GEDU on RGDP. However, at the long run, if the increase in GEDU is sustained, the long run impact of GEDU on RGDP is impact of 5.5480 which is about $7.5 \%$ impact at the long run.

\section{CONCLUSION and Future Scope}

The conclusion which is drawn in the study is that, Federal government annual expenditure made to the educational sector has translated into meaningful growth and thus justified as the GEDU impacts the economic growth in Nigeria both at the short run and at the long run, which is the end result of such expenditure. And since our result was positive and significant both at the short and long run, it shows that our policy makers can make a good plan for either short, medium or long term for education in our country. This finding is consistent with Greg and Agboro (2014). The Federal government expenditure in education has direct and significant effect on Nigeria's economic growth. This is consistent with the a priori 
expectation. Conclusively, the general lesson that emerges from the study is that investment in education could bring about economic growth in Nigeria, but it appears that inadequate financing had ramified the Nigerian educational sector.

This section presents policy recommendations in line with the major findings of the study. It also suggests some guidelines for future researchers.

In the experiment carried out in the study, the results also show that greater impacts in terms of economic growth could be expected from targeting Federal government expenditure in education both in the short run and in the long run. As indicated in results, economic performance can be improved significantly when government resources are reallocated from unproductive areas to the different target areas, with the most positive over-all effects when education is targeted. Because the effect of education on labour cut across to every other sectors in the country. For example, if government can increase her allocation to $20 \%$ of her annual budget, though lesser than the international standard, it will have a robust impact on economic growth of this country. 


\section{References}

[1] Yogish, A. (2006) Growth without scale effects. Journal of Political Economy, 106 (1), 41-63.

[2] Enueme, Chika (1999) Education and Technology: Implications for Economic; Delta state University, Abraka.

[3] Adeyemo, B. (2009) Determinants of Educational Outcomes in Nigeria, European Journal of Social Sciences, 15 (4): 501-511.

[4] Omonkalo, D. G. (2014) An Analysis of Federal Government Expenditure in the Education Sector of Nigeria: Implications for National Development. Journal of Social Science, 9(2):105-110.

[5] Abiodum, L. N. \& Iyiola, W.T. (2011). Education and Economic Growth: The Nigerian Experience. Journal of Emerging Trends in Economics and Management sciences, 2(3): 225-231.

[6] Oluwatobi, S.O \& Olurani, I.O. (2011); "Government Expenditure on Human Capital Development: Implications for Economic Growth in Nigeria". Journal of Sustainable Development, Vol. 4, No. 3; June.

[7] Greg, E. E \& Agboro D. E. (2014) The determinants of public expenditure on educational infrastructural facilities and economic growth in Nigeria. E3 Journal of Business Management and Economics Vol. 5(6). pp. 152-161. 
Article DOI: 10.46654/IJRESD.11714

\section{Appendix1}

Table 2.1: Federal Government Budgetary allocation to Education in Nigeria. 1980-2018

\begin{tabular}{|l|l|l|l|}
\hline Year & $\begin{array}{l}\text { Allocation to Edu. As } \\
\text { of total budget }\end{array}$ & Year & $\begin{array}{l}\text { Allocation to Edu. As } \\
\text { of total budget }\end{array}$ \\
\hline 1980 & 4.95 & 2000 & 8.36 \\
\hline 1981 & 6.45 & 2001 & 7.00 \\
\hline 1982 & 8.09 & 2002 & 5.9 \\
\hline 1983 & 4.04 & 2003 & 1.83 \\
\hline 1984 & 4.49 & 2004 & 10.5 \\
\hline 1985 & 3.79 & 2005 & 9.3 \\
\hline 1986 & 2.69 & 2006 & 11.00 \\
\hline 1987 & 1.93 & 2007 & 8.09 \\
\hline 1988 & 2.40 & 2008 & 13.0 \\
\hline 1989 & 3.55 & 2009 & 6.54 \\
\hline 1990 & 2.83 & 2010 & 6.40 \\
\hline 1991 & 1.09 & 2011 & 1.69 \\
\hline 1992 & 3.86 & 2012 & 10.0 \\
\hline 1993 & 5.62 & 2013 & 8.70 \\
\hline 1994 & 7.13 & 2014 & 10.6 \\
\hline 1995 & 7.20 & 2015 & 9.5 \\
\hline 1996 & 12.23 & 2016 & 8.5 \\
\hline 1997 & 17.59 & 2017 & 5.9 \\
\hline 1998 & 10.27 & 2018 & 6.4 \\
\hline 1999 & 11.12 & & \\
\hline 50495 & & & \\
\hline
\end{tabular}

Sources: Central Bank of Nigeria (2019) statistical bulletin. 
Article DOI: 10.46654/IJRESD.11714

\section{Appendix2}

Dependent Variable: RGDP

Method: Least Squares

Date: 01/02/20 Time: 01:43

Sample (adjusted): 19802018

Included observations: 39 after adjustments

\begin{tabular}{lrlrr}
\hline \hline \multicolumn{1}{c}{ Variable } & Coefficient & Std. Error & t-Statistic & Prob. \\
\hline \hline C & 52187.54 & 27231.34 & 1.916451 & 0.0313 \\
GEDU & 0.414320 & 0.117322 & 3.531479 & 0.0375 \\
\multicolumn{1}{c}{ RGDP(-1) } & 0.925321 & 0.025231 & 36.67358 & 0.0007 \\
\hline \hline R-squared & 0.884413 & Mean dependent var & 424742.7 \\
Adjusted R-squared & 0.834101 & S.D. dependent var & 246251.5 \\
S.E. of regression & 31716.38 & Akaike info criterion & 23.62225 \\
Sum squared resid & $3.12 E+10$ & Schwarz criterion & 23.54383 \\
Log likelihood & -399.0696 & Hannan-Quinn criter. & 23.69708 \\
F-statistic & 929.1532 & Durbin-Watson stat & 1.582312 \\
Prob(F-statistic) & 0.000000 & & \\
\hline \hline
\end{tabular}

